\title{
Service Satisfaction: The Case of a Higher Learning Institution
}

\section{in Malaysia}

\author{
AliReza Jalali \\ School of Management, Universiti Sains Malaysia \\ E-mail: arjiaa@yahoo.com \\ Md. Aminul Islam \\ School of Business Innovation and Technopreneurship, Universiti Malaysia Perlis \\ E-mail:amin@unimap.edu.my \\ Ku Halim Ku Ariffin \\ School of Business Innovation and Technopreneurship, Universiti Malaysia Perlis \\ E-mail:ku.halim@unimap.edu.my
}

\begin{abstract}
This research attempted to find out factors that affect students' satisfaction in a higher learning Institution. The students were randomly selected from degree, masters and $\mathrm{PhD}$ programs to evaluate the level of students' satisfaction. The primary data source was a questionnaire that was distributed to the students. The researchers collected 165 completed questionnaires out of a total of 190. Four factors were chosen as independent variables namely; gender, race, student status and CGPA. This study showed that the overall services offered by the university were moderate from students' perspective. Findings showed that the academic-related activities are more important than non academic-related such as the availability of financial advice etc. It can be inferred from the findings that the academic activities should not be limited to classroom activities only. It must cover everything that can develop and instill good values, attitude, character and strong personality. Universities world-wide are now competing both nationally and internationally. In order to attain new students and retain current students they should aim to enhance student satisfaction and reduce student dissatisfaction. This can only be achieved if all services that are related to academic life such as implicit services, explicit services and physical services are delivered to a suitable standard. We also noticed that student status have an important influence on the perception of service quality. This is probably because student expectation increases as they have more contact with the university. Another element that also has influence on the perception of service quality is race and nationality. In relation to this, the academic or non-academic staffs that prepared services directly for the students should be able to identify and understand different levels of student expectations across years of study (from first year to final year) and races.
\end{abstract}

Keywords: Students' satisfaction, Service quality, Students' expectation, Higher learning institution, Malaysia

\section{Introduction}

Currently every university over the world tries to become a world class university. In fact quality in higher education is relative concept given the number of various stakeholders involved (Tam, 2001) which ranges from the single student as a primary customer (Hill, 1995), to the whole of the society (students, parents, staff, employers, business and legislators) (Rowley, 1997). Based on the philosophy, vision and mission of a faculty, it is obvious that the faculty consistently focuses on quality education and tries to be very dynamic in the quality approach and its technique. Three characteristics of service exit (1) they are physically intangible (2) it is an activity not a thing, (3) production and consumption are simultaneous in some manner (Gronroos, 1983). Service quality is "a goal judgment, or attitude, relating to the superiority of the service" (Parasuraman, Zeithmal, \& Berry, 1988, p.16) and it continues to increase importance as service industries grow and outnumber manufacturing organizations (Strobacka, Standuik, \& Gronroos, 1994) the need of QA imposed by the ministry of education and it could be seen in QMS ISO 9001:2000 certification and the effort put by all the staffs in fulfilling and committing to the requirements of the QA. One of the most important issues which are mentioned in both standards (ISO \& QA) is meeting customer requirements and satisfactions. The strategic success of a service organization depends on the ability of service providers to enhance their images by consistently meeting or exceeding customer's service expectation.

Service quality, per se, is inherently difficult to define and measure and has been the subject of much debate generally over the last two decades (Dale, 2003). It is agreed that service quality has a relationship to customer satisfaction but it is not exactly equal to customer satisfaction, although the relationship between these two constructs has also been the cause of considerable debate with the raft of literature on the topic. Some researchers such as Bitner (1990) ; Bolton 
and Drew (1991); Parasuraman et.al (1988) believed that customer satisfaction is a precursor of service quality, while others, for example, Hoisington and Naumann (2003) ; Spreng and Mackoy (1996) ; Woodside, , Frey, and Daly, (1989), cited in Lee, Lee, and Yoo, (2000), believed that it is service quality that would lead to customer satisfaction. This research follows the latter concept, i.e. the service quality causes customer satisfaction. Perceived High Education (HE) service quality could be the product of a number of service encounter evaluations by students (Hill, 1995). Hill (1995) recognized that the personal attention to the students may be limited because of the lack of resources among the higher learning institutions.

Cadotte and Turgeon's (1988) discovered that a few number of variables determinants could be classified as "Satisfaction", "Dissatisfaction", "Critical" or "Neutrals". A Dissatisfier is some aspect or features that the limitation of these causes dissatisfaction, but the existence of which doesn't cause satisfaction, for example the lack of car park in the university might cause dissatisfaction but its presence may not surely create satisfaction. But the lack of which doesn't lead to dissatisfaction. Critical are those aspects which are both satisfiers and dissatisfiers, i.e. presence leads to satisfaction and absence leads to dissatisfaction, and Neutrals are those aspects whose presence does not lead to satisfaction and absence does not cause dissatisfaction. Johnson (1995) posited that determinants of service quality as originally identified by Parasuraman, Zeithaml, And Berry, (1985) they were not absolutely two sides of the similar coin and that changing all the factors that make customer dissatisfied does not really create satisfied customers. He discovered that while a determinant might be classified important to customers of a special service it may cause satisfaction but not necessarily dissatisfaction. This reflects Herzberg, Mausner, and Snyderman, (1959), original work on satisfaction at work. They found that specific factors lead to job satisfaction (they termed these motivators) while others lead to absence of dissatisfaction (termed hygiene factors). A key distinction between the motivators and the hygiene factors was that where as motivators cause satisfaction the hygiene factors only prevent dissatisfaction.

The purpose of this research is to measure the student satisfaction in a higher learning institution based on their demographic factors and academic factors and we need to mention that we assume students as primary customers of the universities (Hill, 1995). This survey is aimed at post graduate and undergraduate students to seek their views on a number of aspects of teaching, assessment and support provided by their university and its courses. Because the service quality in education becomes more challenging and complex, it is hoped that the results will ultimately be used by Government and funding Bodies to produce league table of university performance. The position of a university in any league tables will impact ultimately on its image. Image has a strong impact on the retention of current students and the attraction of potential students (James, Baldwin \& McInnis, 1999) and also research could provide valuable references for the universities. While formulating their service qualities to enhance student satisfaction, the universities seriously need to perform the requirement of quality assurance standard regulated by the ministry of higher education of Malaysia. Higher education institution in Malaysia contains of 20 public universities, 5 foreign universities Branch Campus( 3 from Australia), 22 private universities, 532 non universities status private Higher Education institutions and 21 polytechnics-Government (Verghese ,2007). The competition between the public and private universities is increasing rapidly. The quality level of service that students receive is one of the main satisfaction evaluation criterions in this competitive market. Many different items have a direct or indirect impact on perception of customer from the service they received. Cost, time, staff's treatment are some of them. One of the most important factors that the universities need to fulfill is to review regularly the quality of education and services given to the student to make student satisfied as a primary customers of the universities (Hill, 1995) .The position of the universities in any league tables will impact ultimately on its image. Image has significant effect on the retention of current students and the attraction of potential students (James et al, 1999). Therefore the central problem for this study can be defined as to what extend service quality affect student satisfaction in a higher learning institution in Malaysia.

\section{Literature Review}

Importance of customers' satisfaction in businesses is as vital as air for human being. All businesses seek long life customers, which is the fundamental essence of customer satisfaction. Huge improvement in the world wide demand for international higher education has been anticipated, increasing from the present 1.8 million customers to 7.2 million by 2025, with Asia, particularly Malaysia and India and China, representing 70 percent of this growth (Bohm, Davis, Meares, \& Pearce, 2002). To completely capitalize on this improvement, it would be significant for all universities to understand Asian consumers, in particular those countries that have more students in the universities which are located in Malaysia.

Long life customers particularly highlighted in service-oriented companies where they offer enticements thorough their special promotions, steal deals and loyalty/reward programs. Satisfaction is an internal feeling of a person that is resulted by comparing the quality of a perceived performance or a delivered good to what extend he or she 
expected before. Customers can be dissatisfied, satisfied and delighted if the performance they receive falls matches or exceed their expectations, respectively (Kotler, 2006). In this survey we will examine the relationship between to concept of customer satisfaction in service industry specifically in educational sectors and the service quality that is offered by universities. Service industry is one of the three main industrial categories of a developed economy. Services are defined in conventional economic literature as "intangible goods". So it is difficult for potential customers to understand what they will receive and what value it will hold for them. One of the measurement tools for measuring these intangible goods is the concept of SERVQUAL model.

\subsection{Education in Malaysia}

When Malaysia became independent, education in Malaysia has experienced huge changes and evolution. The Ministry of Education has converted the old system into the

Cohesive national education system, responding to the national aspiration, economic progress and technological developments by converting its philosophy and focus over the year (Education in Malaysia, 2001).

The goals of higher education systems in Malaysia are as follows:

1) To advance national integration and agreement

2) To meet the high-level manpower requirements of the country

3) To build a advanced society, with the modern proficiency and technology

(Noran \& Ahmad, 2005)

In order to participate in the continuous economic and social improvement, a university is responsible to produce knowledgeable and capable graduates to meet the human resource needs of organization in the business, industrial and service sectors including public services. Thus, delivering quality service has become an important goal for most higher education institutions. Moreover, Malaysia is ambitious to become a regional center for educational excellence. It is important to look into the areas of deficiency in order to have excellent institutions of higher learning. Private universities are growing rapidly in Malaysia over the years. The objective of private universities is to provide an alternative road for tertiary education for those who favored to continue higher education locally or for those who were unsuccessful to enter into local/public universities.

Besides, the public universities have franchise academic programs with many private universities. In turn, the latter also corporate with famous foreign universities. In line and have interested the attraction of many foreign students. Although the universities sector is still an appeared market, the higher education service providers have to continuously control the quality service prepared. Also, the perceived performance and the expectation of the students are also important factors to look into when formulating strategies. This study will discover on the student's satisfaction component which has the significant impact on student's loyalty. The focus on this area will provide a useful insight about the perception of students towards service providers of higher educational institutions.

\subsection{View point of Private and Public University}

Teaching must be translated widely; teaching should also be responsive to student's requirements and the conditions necessary for good teaching. This means that the conditions necessary for good teaching must be taken seriously and the environment and surrounding of a university must also be considered. As Datuk Hassan Hashim, Deputy Director-General of Education said "sometimes a college claims that they are good but upon enrollment, students discover that it is at the top floor of a shop-lot with not enough lecturers" (Gomez, The star, 29 Aug 2001). Now a day there are sixteen public universities, and twenty four private universities and five foreign universities branch campuses (Education guide Malaysia, 2004). In order to encourage the students to continue their education in local universities the government tries to inspire public universities to corporate with private universities in order to create more educational situation locally. Because of the increasing number of franchise programs and the number of full time undergraduate students who are taken in or received in public universities, the lecturer teaching program has interrupted because they have to pay attention to students in their own campus as well as the franchise programs at private collages (Simrit, The star, 07 April 2002).

\subsection{Factors Impacting On Student Satisfaction}

A survey has recently reported on the influence of facilities on the undergraduate student choice of university (Price, Matzdorf, Smith, \& Agahi, 2003). They surveyed a number of universities over two years in order to determine students' reasons for choosing a special university. The average finding for two years were really similar the eight more important reasons are; it had the right course, availability of computers, quality of library facilities, good teaching reputation, availability of "quiet" areas, availability of areas self-study, quality of public transport in the town/city and a friendly attitude towards students. It is clear that universities facilities are one of most important 
things that affect on students decision to enroll. Student satisfaction decreased when class sizes are larger in earlier cohorts, and when students are talking compulsory core models rather than optional modules (Cloes, 2002). The quality of any of the service encounters, or "moment of truth" (Carlzon, 1989) experienced by customers forms part of their overall impression of the whole service provided, (Dale, 2003) and by implication, their impression of the organization itself. All universities should manage all aspects of the student's interaction with all of their service offerings and in some other aspects involving its people in order to deliver high quality services to their students. Services are delivered to people by people and the moments of truth can make or break a university's image (Banwet \& Datta, 2003). "In order to deliver total student satisfaction, all employees of the university should adhere to the principles of quality of customer service, whether they be front-line contact staff involved in teaching or administration, or non-contact staff in management or administrative roles (Gold, 2001; Low; 2000, Banwet \& Datta, 2003).A recent survey has been done by Sohail and Shaikh (2004) contain of 310 all male saudi Arabian students attending the king Fahd University of Petroleum and Minerals, found that "contact personnel" was the most influencing factor in student's evaluation of service quality. However, physical environment, layout, lighting, classrooms, appearance of building and ground and the overall cleanliness also significantly contributed to student's concepts of service quality.

A study done by Galloway (1989) about the role of the faculty administration office in one UK University on student perception of service quality. He found that it impacted directly on students and influenced their perceptions of service quality. The academic and technical staff within the faculty is impacted by the office performance. It found that these front-line staff had influence on student satisfaction and other customers. The most important factors of quality were found to be: i) Office has a professional appearance; ii) Staff dresses smartly; iii) Never too busy to help; and iv) Opening hours are personally convenient.

Satisfied customers are loyal, and that satisfied students were likely to attend another lecture delivered by the same lecturer or opt for another module or course taught by him or her. (Banwet \& Datta, 2003). In this survey of 168 students that attended in four lectures by the same lecturer, covering perceived Service quality, significance and post-visit intentions, they found that student pay more attention on the result of the lecture( skills and knowledge received, capability of class notes and reading materials, strong point and the weak point of the lecture and view point of teachers on their work) than any other dimensions. This survey supports the finding of Schneider and Bowen (1995), they found that the quality of core service influences the overall quality of the service perception. For university the core service university method is still the lecture. The student's intention to re attend at or recommend lectures is related to their perceptions about the quality and satisfaction they got from attending the last lectures. And also it is supported by the survey done by Hill, Lomas, and MacGregor, (2003), who utilized focus groups to determine what quality education meant to students .

The most significant theme was the quality of the lecturer consists of class room delivery, feed back to students during the session and on assignment, and the relationship among the student in the class. In order to measure the influence of higher education (HE) on student's academic, social and personal growth, the Hong Kong university found that the result of university going students are changed intellectually, socially, emotionally and culturally( Tam, 2002). This growth was evidenced as students progressed from one year to another as their university career developed. Is this also the case with student's perception of service quality and satisfaction? A number of researchers have suggested that this might indeed be the case (Hill, 1995) although finding reliable and valid data to support such a stance is difficult. This study aims to determine if there are differences in those aspects of a university service that student consider important, as well as their satisfaction levels, associated with their year/level of study, i.e. first, second and third.

\subsection{Customer Satisfaction and Customer Loyalty}

Keeping customer satisfied is what leads to customer loyalty. Jones and Sasser Jr, 1995; found after examine thirty two different organization with 5 different market that the relationship between loyalty and satisfaction is linear which means that when the satisfaction rises the loyalty rises too. A higher customer satisfaction lead to number of improvements like higher customer loyalty, higher consumption of the service, acquisition of further customers (Mele, 2003). However in markets that there is a intense competency there is no relationship between customers and loyalty it means that there is a difference between loyalty and satisfied or completely satisfied customers. To put it simply if satisfaction ranked on 1-5 scale from completely dissatisfied to completely satisfied, the 4 's - though satisfied- were six times more likely to defect than the 5's.

Customer loyalty reveals itself in many form of customer behavior:

Intend to re-purchase;

Primary behavior - organization has access to information on various transactions at the customer level and can 
track five categories that show actual customer re-purchasing behavior; decency, frequency, amount, retention, and longevity; and

Secondary behavior - e.g. Customer referrals, endorsement and spreading the word are all extremely important forms of consumer behavior for an organization.

By translating this in to university services, this covers intent to study at a higher level within the same institution, how frequently and recently a student used ancillary services, such as the library, creating and IT services, and lastly the willingness to recommend the institution to friends, neighbors and fellow employees.

\subsection{Factor Influence the Evaluation of Service Quality}

\subsubsection{Gender}

A study has done before by Khantanapha (2000) found that there is no difference between man and women MBA students in expectation of service quality. The analysis of variance results for expectations and gender shows there is no difference between men and women. However, there are significant differences in perceptions of actual service quality between men and women in five different universities in Thailand. Another research by Joseph and Joseph (1998) found that there is no significant difference between male and female. However, the study done by Soutar and McNeil (1996) and Kamal and Ramzi (2002), indicates that gender factor place an effect on the satisfaction scale of service quality which male student were found to be more satisfied than female.

\subsubsection{Race}

Tomovick, Jones and Al-Khatib (1986) examined the factors that influence the service quality perceptions of international students in US business schools. The finding of the research discovered that the international business students considered tangibles (which appealing facilities) to be one of the most important elements in the service quality of educational institution. Malhotra (1994) in his research compared the determinants of service quality between developing and developed countries and one of the findings of the study is that environmental differences between the two groups of countries can have changeable influences on service quality determinants. Another research done by Winsted (1997) on how customers in US and Japan evaluate service encounters, found that studies examining service encounters components in the two countries.

\subsubsection{Student Status}

A study by Kamal and Ramzi (2002) on a assuring quality service in private university has found that student from the faculty of business and economics give lower total mean rating on the overall satisfaction scale than students from the faculty of arts and architecture and design. Furthermore those who are studying in the faculty of arts were more satisfied in comparison with those studying in the faculty of engineering. The research showed that there are differences on the satisfaction of service quality based on field of study. A research by Oldfield \& Baron (2000) on student perception towards academic staff in a UK university business and management faculty revealed that there are differences between those who are senior and the lower level students.

\subsection{4 (CGPA)}

In education, a grade (or mark) is a teacher's standardized evaluation of a student's work. In some countries, evaluations can be expressed quantifiable, and calculated into a numeric grade point average (GPA), which is used as a metric by employers and others to assess and compare students. A cumulative grade point average (CGPA) is the mean GPA from all terms, whereas GPA may only refer to a single term (Farish, 1972)

\section{Research Methodology}

Data for this study were collected from a higher learning institution through questionnaires. Survey questionnaires were distributed to randomly selected students who were pursuing degree, masters and $\mathrm{PhD}$ programs. A survey questionnaire was designed to gather information on the students' satisfaction. The statements and questions were closed-ended, whereby the choice is limited to fixed response on specific points on a Likert-type and nominal scales. The questionnaires were distributed to the respondents to a total of 190 of respondents along with permission letters. It consists of students with different genders, different age groups, various background and different types of courses at the institute. The questionnaires were prepared in English. The independent variables in this study are Demographic factors such as gender, race, student status and CGPA. A quantitative survey was designed to elicit student satisfaction levels across the university's services offering.

The hypotheses for the study are as follows:

HO1: There is no significant difference between full time and part time students on implicit service satisfaction

HO2: There is no significant difference between full time and part time students on explicit service satisfaction 
HO3: There is no significant difference in the satisfaction of implicit service based on nationality

HO4: There is no significant difference in the satisfaction of explicit service based on nationality

HO5: There is no significant difference in the satisfaction of implicit service based on race

HO6: There is no significant difference in the satisfaction of explicit service based on race

HO7: There is no significant difference in the satisfaction of implicit service based on CGPA

HO8: There is no significant difference in the satisfaction of explicit service based on CGPA

\section{Results}

A total of 190 questionnaires were distributed to undergraduate and graduate students. From the total number of 190 questionnaires distributed, 165 were returned; the response rate was about $84.61 \%$. Some of the questionnaires were not fully completed by respondents and hence abandoned from analysis. This results a total of 150 usable data. Graduates consist of 28 and 107 master degree and 15 who are studying in Phd. The demographic profile of respondents is shown in table 4.1. As comfort sampling was used in this research the percentage of undergraduate students were (18.7\%), master students were $(71.3 \%)$ and those who are doing Phd were $(10 \%)$. A Greater part of the respondents were female $(53.3 \%)$ as compared to male (46.7\%). the races were categorized in to Malay (42.7\%), Chinese (30.7\%), Indian (10\%) and others (16.7\%). The majority of the nationality of the students was local (78.7\%) and international (21.3\%). Most of the students were full-time students $(50.7 \%)$ and part time Students (49.3\%). Most of the students were private employee (44\%), government employee (24\%), student (23.3\%), self employee (4.0\%) and others (4.7\%). The majority monthly income falls under RM2000 and most of the respondents have the monthly income in range of RM 3001- RM 4000. As smaller percentage of students have monthly income in the range of RM 2001- RM 3000. A majority of the respondents had the CGPA more than three and the small number of the respondents had CGPA less than_three and no one had CGPA bellow two. And the most of the respondents had the age bellow 33 .

\subsection{Reliability Analysis}

The items that represent each individual factor were subjected to reliability analysis. The computation of the Cronbach's alpha would determine the extent of agreement between respondents for each dimension. A higher score will indicate a higher reliability, with a range from 0 to 1 . All dimensions in this study have high levels of reliability and are well above the cut-off value of 0.70 as suggested by Nunnally and Bernstein (1994) with the lowest registering a value of 0.92 (Implicit Service Satisfaction) and the highest .94 (explicit Service Satisfaction). The rest of the variables implicit service importance (.93) and explicit importance (.92) have satisfactory alpha value. The alpha coefficients are reported in the similar tables of factor analysis to ease the comparison between the representative extracted factors and their reliability scores.

\subsection{Findings}

After passing the validity and reliability analysis, the items representing their respective factors were then averaged. The mean was applied as a measure of central tendency, which indicated that all variables were above their midpoint level as indicated in Table 1. Table 1 shows the most satisfaction (i.e. list of the top ten starting from the highest value) and least satisfaction (i.e. list of the bottom ten starting from the lowest value).

Insert Table 1 Here

As can be seen from table 1 the language ability of staff and teaching ability and knowledge level of staff were ranked highly. And most of the students are satisfied with the level of difficulty of the assignments and also the consistency of teaching quality, where as majority of the students are not satisfied the availability of financial advice and also the availability of staff and the level of furnishing and lighting. Table 2 shows most satisfied aspect of full-time and part-time students.

Insert Table 2, Table 3 Here

As can be seen in table 3 there is no significant difference between local and international students for choosing the important items, there are some aspects are really important for the international students such as staff teaching ability, knowledge level of staff and staff availability but the table 4 showed that these items did not have the high rank and it shows that the management must pay attention more to these items. And there are some aspects that are important for local students such as the lecturers, presentation slide and the knowledge level of staff and they satisfied with these items.

Insert Table 4, Table 5 Here

As it can be seen in the table 5 there is no significant differences between different CGPA and there are many 
similar aspects such as the knowledge levels of staff, the lectures and the staff teaching ability and in the table 5 it shows that they are satisfied with these items. Table 6 presents the most satisfied aspect based on gender.

Insert Table 6 Here

\subsection{Level of student satisfaction}

By using descriptive analysis and frequency of student satisfaction we found that the percentage of those students that chose the level of satisfaction moderate was $(76 \%)$ and the percentage of those who chose high was (17.3\%) and those who chose low was $(6.7 \%)$ so the overall level of satisfaction of the higher learning institution was moderate and it shows that if the management and staff of the university pay attention more to the three aspects of services (implicit services and explicit services) they could easily enhance the level of satisfaction in this university.

\subsection{Summary of Major Findings and Results of the Hypotheses}

Synthesizing from the analyses, the following are major findings of the study:

1- There is a significant difference between full time and part time student in the services provided by the university.

2- There is a significant difference in the satisfaction of services based on nationality

3- There is a significant difference in the satisfaction of services based on race.

4- it is partially accepted that there is no significant difference in the satisfaction of services based on income.

5- There is significant difference in the satisfaction of services based on CGPA.

6- There is significant difference in the satisfaction of services based on nationality.

Based on ANOVA which is related to the race we could find that the significant value for implicit service is 0.81 and for explicit service .92 and for physical services is .34 and all more than .05 so we accept Ho. Based on T-test which is related to the nationality we could find that the significant value for implicit service is 0.36 and for explicit services 0.49 and for physical services is 0.79 , so we accept Ho according to the table of T-test which is related to the full-time and part-time students we could find that the significant value which is related to the implicit service is 0.53 and for explicit service is 0.48 and for physical service is 0.42 , so we accept Ho, and by considering the table which is related to the CGPA we could find that the significant value which is related to implicit service is 0.73 and for explicit service is 0.87 and for physical service is 0.37 so we accept Ho.

\section{Conclusions}

This study showed that the overall, services prepared by the university was moderate from students' perspective. This means that the university has enough ability to continue its improvement. This study showed that the academic-related activities are more important than non academic-related such as the availability of financial advice and the level of decoration. The academic activities must not be limited to classroom activities only. It must cover everything that can develop and instill good values, attitude, character and strong personality. It also should take in to account the learning environment which includes good infrastructure and support service. All of these must be offered concurrently in order to produce good graduates. Universities world-wide are now competing both nationally and internationally. In order to attain new students and retain current students they should aim to enhance student satisfaction and reduce student dissatisfaction. This only can be achieved if all the services that related to academic life such as implicit services, explicit services and physical services must be delivered to a suitable standard. The students are the most significant judges of whether or not this has been achieved therefore students satisfaction surveys should be undertaken on a regular basis.

We also noticed that student status have an important influence on the perception of service quality. This is probably because student expectation increases as they have more contact with the university. Another element that also has influence on the perception of service quality is race. In relation to this, the academic or non-academic staffs that prepared services directly for the students should be able to identify and understand different levels of student expectations across years of study (from first year to final year) and races.

Further research is needed to determine the parameters of the students' 'zone of tolerance'. This is important for service provider to gradually improve the quality and allocate resource accordingly. Owing to resource restrictions, rules, regulation, as well as policies, in some instances it is almost impossible for public universities to provide everything that student want. Future research should focus on the perception of service quality from other stakeholders (such as internal customer, government, industries, etc.). A comprehensive study would help the faculty to review and 'beef-up' its overall service quality in the education sector.

\section{References}

Banwet, D.K. and Datta, B. (2003). "A study of the effect of perceived lecture quality onpost-lecture intentions", 
Work Study, Vol. 52 No. 5

Bitner, M.J. (1990). "Evaluating service encounters: the effects of physical surroundings And employee responses", Journal of Marketing, Vol. 54

Bolton, R.N. and Drew, J.H. (1991). "A multistage model of customers' assessments of Service quality and value”, Journal of Consumer Research, Vol. 17

Cadotte, E.R. and Turgeon, N. (1988). "Dissatisfiers and satisfiers: suggestions for Consumer complaints and compliments", Journal of Consumer Satisfaction, Dissatisfaction and Complaining Behaviour, Vol. 1

Carlzon, J. (1989). Moments of Truth, Harper Collins, New York, NY.

Coles, C. (2002). "Variability of student ratings of accounting teaching: evidence from a Scottish business school", Interrnational of journal management education, Vol. 2 No. 2

Dale, B.G. (2003). Managing Quality, 4th ed., Blackwell Publishing, Oxford.

Education in Malaysia. (2001). A journey to excellence. AG Grafik Sdn Bhd, 111-119

Gold, E. (2001). Customer Service: A Key Unifying Force for Today's Campus,

Netresults, National Association of Student Personnel Administrators, 22 January, available at: www.naspa.org/netresults, cited in Banwet, D.K. and Datta, B. (2003). "A study of the effect of perceived lecture quality on post-lecture intentions", Work Study, Vol. 52 ,No .5

Groonroos, C. (1983). Strategic Management and Marketing in the Service Sector. Swedish School of Economics and Business Administration, Helsingfors.

Groonroos, C. (1990). Service Management and Marketing: Managing the Moments of Truth in Service Competition, Lexington, MA: Lexington Books.

Herzberg, F., Mausner, B. and Snyderman, B.B. (1959). Motivation to Work, Wiley, New York, NY.

Hill, F.M. (1995). "Managing service quality in higher education: the role of the student As primary consumer", Quality Assurance in Education, Vol. 3 , No. 3

Hill, Y., Lomas, L. and MacGregor, J. (2003). "Students' perceptions of quality in higher education”, Quality Assurance in Education, Vol. 11, No. 1

Hoisington, S. and Naumann, E. (2003). "The loyalty elephant", Quality Progress

Johnston, R. (1995). "The determinants of service quality: satisfiers and dissatisfiers", International Journal of Service Industry Management, Vol. 6 , No. 5

Kotler, Philip and Karen F.A. Fox (1995). Strategic Marketing for Educational Institutions, Second Edition, Prentice-Hall, Inc., Englewood Cliffs, New Jersey.

Lee, H., Lee, Y. and Yoo, D. (2000). "The determinants of perceived service quality and its relationship with satisfaction", Journal of Services Marketing, Vol. 14 , No. 3

Low, L. (2000). Are College Students Satisfied? A National Analysis of ChangingExpectations, Noel-Levitz, Iowa City, IA, cited in Banwet, D.K. and Datta, B. (2003). "Study of the effect of perceived lecture quality on post-lecture intentions", Work Study, Vol 52 , No 5

Mele, R. (2003). Economia e gestione delle imprese di pubblici servizi tra regolamentazione mercato, Cedam, Padova

Noran, F.Y. \& Ahmad, M.A.(2005).Business of Higher Education in Malaysia: Development and Prospectes in the New Millennum. Retrieved on December 152005 from http:/WWW.mahdzan.com.

Parasuraman, A., Zeithaml, V.A. \& Berry, L.L. (1985). A conceptual model of service quality and its implications for future research. Journal of Marketing, Vol. 49, No. 4

Price, I., Matzdorf, F., Smith, L. and Agahi, H. (2003). "The impact of facilities on student choice of university", Facilities, Vol. 21, No. 10

Rowley, J. (2003). "Retention: rhetoric or realistic agendas for the future of higher education", The International Journal of Educational Management, Vol. 17, No. 6

Sekaran, U. (2003). Research methods for business: A skill-building approach (4 th ed.). New york : John Wiley \& Sons, Inc.

Schneider, B. and Bowen, D.E. (1995). Winning the Service Game, Harvard Business School Press, Boston, MA. 
Sohail, M.S. and Shaikh, N.M. (2004). "Quest for excellence in business education: a study of student impressions of service quality”, The International Journal of Educational Management, Vol. 18 , No. 1

Spreng, R.A. and MacKoy, R.D. (1996). "An empirical examination of a model of Perceived service quality and satisfaction”, Journal of Retailing, Vol. 72 , No. 2

Tam, M. (2002). "Measuring the effect of higher education on university students", Quality Assurance in Education, Vol. 10 , No. 4

Woodside, A.G., Frey, L.L. and Daly, R. (1989). "Linking service quality, customer Satisfaction and behavioural intentions", Journal of Healthcare Marketing, Vol. 9.

Table 1. Most Satisfied and Least Satisfied Aspects For The Students (Overall)

\begin{tabular}{|c|c|c|c|c|}
\hline Ranking & Most satisfied & Mean & Least satisfied & Mean \\
\hline 1 & Staff language ability & 3.64 & The availability of financial advise & 3.21 \\
\hline 2 & Staff teaching ability & 3.57 & The availability of staff & 3.26 \\
\hline 3 & The knowledge level of staff & 3.56 & $\begin{array}{l}\text { The feeling that the rewards gained are consistent with } \\
\text { the effort you put into assessment }\end{array}$ & 3.27 \\
\hline 4 & The level of furnishing & 3.55 & The level of furnishing problem & 3.29 \\
\hline 5 & Supplementary handout document & 3.55 & The concern shown when you have problem & 3.29 \\
\hline 6 & $\begin{array}{l}\text { The lecture theaters and the lectures and the level of } \\
\text { difficulty of the assignments }\end{array}$ & 3.51 & The availability of help & 3.30 \\
\hline 7 & The consistency of teaching quality & 3.49 & $\begin{array}{l}\text { Ease of making appointments with staff and the } \\
\text { competence of staff }\end{array}$ & 3.31 \\
\hline 8 & The quality of the students study support & 3.49 & The level of lighting & 3.31 \\
\hline 9 & $\begin{array}{l}\text { The university environments ability to make you feel } \\
\text { comfortable and the level of the difficulty of the work } \\
\text { load }\end{array}$ & 3.48 & The feeling that your best interest are being served & 3.34 \\
\hline 10 & $\begin{array}{l}\text { The sense of the professionalism conveyed by the } \\
\text { ambience in the tutorials }\end{array}$ & 3.47 & $\begin{array}{l}\text { The respect for you feeling concerns and opinion, the } \\
\text { level of decoration and the approachability of teaching } \\
\text { staff }\end{array}$ & 3.37 \\
\hline 11 & The friendliness of teaching staff & 3.45 & $\begin{array}{l}\text { The sense of professionalism conveyed by the ambience } \\
\text { in the tutorials and the level of ancillary services }\end{array}$ & 3.38 \\
\hline 12 & The recommended module text and the tutorials & 3.43 & Tutorial rooms and the level of lighting & 3.41 \\
\hline
\end{tabular}

Table 2. Most satisfied aspect for full-time and part-time students

\begin{tabular}{|l|l|l|}
\hline Ranking & Most satisfaction(full-time) & Most satisfaction(part-time) \\
\hline 1 & Staff language ability & Staff language ability \\
\hline 2 & The knowledge levels of staff & The level of difficulty of the assignments \\
\hline 3 & The consistency of teaching quality & The level of difficulty of subject contents \\
\hline 4 & Staff teaching ability & Staff teaching ability \\
\hline 5 & Presentation slide & Presentation slide \\
\hline 7 & The level of difficulty of subject contents & The quality of the student study support \\
\hline 8 & The lecturer theaters & $\begin{array}{l}\text { The sense of professionalism conveyed by the ambience in } \\
\text { the lectures }\end{array}$ \\
\hline 9 & The university environments ability to make you feel comfortable & The knowledge level of staff \\
\hline 10 & Tutorial rooms & The level of difficulty of the work load \\
\hline
\end{tabular}


Table 3. Most satisfied aspect of services for the local and international student

\begin{tabular}{|l|l|l|}
\hline Ranking & Most satisfied(international) & Most satisfied (local) \\
\hline 1 & Staff language ability & Staff language ability \\
\hline 2 & The level of difficulty of the subjects contents & Staff teaching ability \\
\hline 4 & The level of lighting & The lecturers \\
\hline 5 & The university environment's to make you feel comfortable & Supplementary handout document \\
\hline 6 & Tutorial rooms & The knowledge level of staff \\
\hline 7 & The consistency of teaching quality & The sense of professionalism conveyed by the ambience in the lecture \\
\hline 8 & The knowledge levels of staff & The level of difficulty of the subject contents \\
\hline 9 & The level of ancillary service & The level of difficulty of the assignments \\
\hline 10 & Thesentation slide & The lecturer theaters \\
\hline
\end{tabular}

Table 4. The most satisfied aspects based on race

\begin{tabular}{|c|c|c|c|c|}
\hline Rank & Malay & Chinese & Indian & Others \\
\hline 1 & Staff teaching ability & Staff language ability & The lectures theater & The lecture theaters \\
\hline 2 & The lectures & $\begin{array}{l}\text { The level of difficulty of } \\
\text { the work load }\end{array}$ & Staff language ability & The consistency of teaching quality \\
\hline 3 & Presentation slide & Presentation slide & Presentation slide & $\begin{array}{l}\text { The university environment's ability } \\
\text { to make you feel comfortable }\end{array}$ \\
\hline 4 & $\begin{array}{l}\text { The sense of professionalism conveyed } \\
\text { by the ambience in the lectures }\end{array}$ & Staff teaching ability & $\begin{array}{l}\text { The quality of the students } \\
\text { study support }\end{array}$ & $\begin{array}{l}\text { The level of difficulty of the subject } \\
\text { content }\end{array}$ \\
\hline 5 & Staff language ability & $\begin{array}{l}\text { The knowledge level of } \\
\text { staff }\end{array}$ & $\begin{array}{l}\text { The feeling that your best } \\
\text { interest are being served }\end{array}$ & $\begin{array}{l}\text { The quality of the student study } \\
\text { support }\end{array}$ \\
\hline 6 & The tutorials & The lectures & The level of lighting & The level of decoration \\
\hline 7 & The knowledge level of staff & $\begin{array}{l}\text { The recommended module } \\
\text { text }\end{array}$ & The knowledge level of staff & The recommended module text \\
\hline 8 & The consistency of teaching quality & $\begin{array}{l}\text { The concern shown when } \\
\text { you have problem }\end{array}$ & $\begin{array}{l}\text { The friendliness of teaching } \\
\text { staff }\end{array}$ & The level of lighting \\
\hline 9 & $\begin{array}{l}\text { The level of difficulty of the } \\
\text { assignments }\end{array}$ & The competence of staff & The availability of help & Presentation slide \\
\hline 10 & $\begin{array}{l}\text { The feeling that your best interest } \\
\text { served }\end{array}$ & $\begin{array}{l}\text { The approachability of } \\
\text { teaching staff }\end{array}$ & The level of difficulty of the & Staff language ability \\
\hline
\end{tabular}

Table 5. The most satisfied aspect based on CGPA

\begin{tabular}{|l|l|l|}
\hline Rank & More than three & Less than three \\
\hline 1 & Staff language ability & Staff language ability \\
\hline 2 & Staff teaching ability & The sense of professionalism conveyed by the ambience in the lectures \\
\hline 3 & The knowledge levels of staff & The tutorials \\
\hline 4 & The level of difficulty of the subject content & Supplementary handout document \\
\hline 5 & Presentation slide & The university environment's ability to make you feel comfortable \\
\hline 7 & The level of difficulty of the assignments & Presentation slide \\
\hline 8 & The consistency of teaching quality & The concern shown when you have problem \\
\hline 9 & The recommended module text & The recommended module text \\
\hline 10 & The lectures & The quality of the student study support \\
\hline
\end{tabular}


Table 6 . The most satisfied aspect based on gender

\begin{tabular}{|l|l|l|}
\hline Rank & Female & Male \\
\hline 1 & Staff language ability & The quality of the student study support \\
\hline 2 & Staff teaching ability & The level of difficulty of the assignments \\
\hline 3 & The knowledge levels of staff & The recommended module text \\
\hline 4 & The lectures & Presentation slide \\
\hline 5 & Presentation slide & Staff language ability \\
\hline 6 & The sense of professionalism conveyed by the ambience in the lectures & The level of difficulty of the workload \\
\hline 7 & The availability of staff & The knowledge levels of staff \\
\hline 8 & The concern shown when you have problem & Staff teaching ability \\
\hline 9 & The university environment's ability to make you feel comfortable & The level of lighting \\
\hline 10 & The level of difficulty of the assignments & Tutorial rooms \\
\hline
\end{tabular}

